\title{
In vitro Anticancer Effects of Vernonia amygdalina Leaf Extract and Green-Synthesised Silver Nanoparticles [Corrigendum]
}

\author{
Joseph J, Khor KZ, Moses EJ, Lim V, Aziz MY, \\ Abdul Samad N. Int J Nanomedicine. 2021;16:3599-
} 3612 .

The authors have advised that the acknowledgment statement on page 3610 is incorrect. The correct acknowledgment is as follows:

\section{Acknowledgment}

This Study received financial support from the Fundamental Research Grant Scheme (FRGS) (FRGS/1/2020/STG01/ USM/03/2), account code: (FRGS 203.CIPPT.6711842) from the Ministry of Higher Education Malaysia.

The authors apologize for this error.

\section{Publish your work in this journal}

The International Journal of Nanomedicine is an international, peerreviewed journal focusing on the application of nanotechnology in diagnostics, therapeutics, and drug delivery systems throughout the biomedical field. This journal is indexed on PubMed Central, MedLine, CAS, SciSearch ${ }^{\mathbb{R}}$, Current Contents ${ }^{\mathbb{B}} /$ Clinical Medicine, $^{2}$
Journal Citation Reports/Science Edition, EMBase, Scopus and the Elsevier Bibliographic databases. The manuscript management system is completely online and includes a very quick and fair peer-review system, which is all easy to use. Visit http://www.dovepress.com/ testimonials.php to read real quotes from published authors. 